\title{
HEMATO-BIOCHEMICAL AND HISTOPATHOLOGICAL CHANGES IN MUD LOACH, Misgurnus mizolepis EXPERIMENTALLY INFECTED WITH Aeromonas sobria
}

\author{
Jin-Ha Yu* , Jung-Jo Han², Dae-Hyun Kim³ ${ }^{3}$, Sung-Woo Park ${ }^{3}$ \\ ${ }^{1}$ Quarantine and Inspection Division, National Fishery Products Quality Management Service, 337 Haeyang-ro, Busan 49111, ${ }^{2}$ Division of \\ Fishery Safety, Gyeonggi Province Maritime and Fisheries Research Institute, 23-2 Sanggwang-gil, Yangpyeong 12513, ${ }^{3}$ Department of \\ Aquatic Life Medicine, Kunsan National University, 558 Daehak-ro, Gunsan 54150, Republic of Korea \\ ${ }^{*}$ Corresponding author, E-mail: psw@kunsan.ac.kr
}

\begin{abstract}
Hemato-biochemical and histopathological alterations in mud loach (Misgurnus mizolepis) infected with Aeromonas sobriawere characterized in the present study. Fish infected with $1 \times 10^{6}$ colony forming units $/ \mathrm{mL}$ of $A$. sobria $(25$ fish $\times 3$ replicates $\times 3$ tanks) and uninfected (control) fish ( 25 fish $\times 3$ replicates $\times 3$ tanks) were kept in laboratory tanks with adequate water parameters, and euthanized at 1,3 , and 5 days post-infection (PI). Infected fish became lethargic and developed rapid opercular movements, pale gills, and cutaneous petechial hemorrhages during the 5-day experimental period. Hemato-biochemical parameters, namely hematocrit, hemoglobin, total protein, total calcium, alkaline phosphatase (ALP) activity, and glucose level were significantly reduced, whereas urea (UA) level, and aspartate aminotransferase (AST), alanine aminotransferase (ALT), and lactate dehydrogenase (LDH) activities were markedly increased in infected fish compared to control fish. Total leukocyte count was higher of infected than in control fish by day $3 \mathrm{PI}$, but dramatically decreased on day $5 \mathrm{PI}$. The leukogram showed the predominance of lymphocytes and neutrophils during the experimental period. Histologically, kidney and spleen showed extensive hemorrhage with cellular necrosis. Liver cells showed severely necrotic foci with karyopyknosis, karyorrhexis, karyolysis, and hyperchromatosis of the nuclear membrane. Thus, A. sobria infection causes hemato-biochemical changes such as anemia, hypoglycemia, hypoproteinemia, hypocalcemia, increased AST, ALT, and LDHactivities, increased UA concentrations, and reduced ALPactivity, and lead to compromised disease resistance, tissue damage, and low survival rates.
\end{abstract}

Key words: Aeromonas sobria; hematology; histopathology; Misgurnus mizolepis

\section{Introduction}

The mud loach, Misgurnus mizolepis (Cobitidae, Cypriniformes), is a freshwater fish that is widely distributed throughout streams, ditches, reservoirs, and rice paddy fields, preferably with a soft muddy bottom, in Korea, Japan, and China (1).

Aeromonas sobria has been isolated from human blood, feces, and wounds $(2,3,4)$, and from wild-spawning gizzard shad, Dorosoma

Received: 14 October 2017

Accepted for publication: 17 April 2018 cepedianum (5), European perch, Perca fluviatilis (6), and mud loach (7). Moribund gizzard shad did not display any clinical signs of disease whereas European perch and mud loach displayed hemorrhage and ulceration on skin and fins.

Hematological parameters and histological changes have been widely used to assess the health status of fish exposed to various diseases, both in laboratory and field studies $(8,9,10,11,12,13)$.

A previous study on A. sobria infecting mud loach described the histopathology of several tissues, the etiology of morbidity and mortality, the characteristics of $A$. sobria, and confirmed 
bacterial toxins using polymerase chain reaction (PCR) (7). To our knowledge, the hematological changes occurring in mud loach infected with $A$. sobria have not been reported so far, although they could provide insight into fish responses to this bacterial infection, its disease process, and on the degree of lesion and metabolic disorder, all of which facilitate disease diagnosis. Thus, the present study investigated changes in clinical signs and evaluated blood chemistry and, tissue pathology in the mud loach, aiming to better characterize its diseased state.

\section{Materials and methods}

\section{Fish}

Three hundred fifty clinically healthy mud loach individuals (average body weight $6.6 \mathrm{~g}$, two years old, both sexes) were collected from a holding fish farm located in Buan-gun, Jeollabukdo, Korea, and transferred to the laboratory alive, within polyethylene bags containing oxygenated water. These fish were acclimatized in a plastic tank (1.5 tonnes) filled with dechlorinated tap water (pH 6.8-7.1; dissolved oxygen 6.0-6.5 mg/L) for 30 days. The tank was continuously aerated and the water temperature was maintained at $20 \pm 1{ }^{\circ} \mathrm{C}$. Approximately $50 \%$ of the water was replaced daily. Ammonia, nitrite, and $\mathrm{pH}$ levels were measured on alternate days using a water-testing kit (Hach, Loveland, CO, USA). Because mud loach is an air-breathing fish, the oxygen level in the tank was not measured. Fish were fed daily with commercial mud loach feed (Woosung Aquafeed, Daejeon, Korea) at 1\% of their biomass until three days before infection. After acclimatization, 300 fish were divided into four groups of 75 fish each distributed across 12 tanks (40-L capacity), each containing 25 fish (experiments were run in triplicate). Before infection, fish in each tank were acclimatized for seven days but not fed, in order to standardize their dietary status. During this period, the water was maintained at $20 \pm 1{ }^{\circ} \mathrm{C}, \mathrm{pH} 6-7$, dissolved oxygen above $6 \mathrm{mg} / \mathrm{L}$, and nitrite below $1 \mathrm{mg} / \mathrm{L}$. All procedures were approved by the Experimental Animal Ethical Committee of the Kunsan National University (Reg. No. 410000100008).

\section{Experimental infection}

Aeromonas sobria (LBH) used in this study was previously isolated from a naturally infected mud loach (7). Before the experimental infection, three consecutive serial passages of the bacteria in mud loach individuals anaesthetized with AQUI-S 10 (Handong Co., Seoul, Korea) in accordance with the manufacturer's manual were executed by the intraperitoneal injection of about $1 \times 10^{7}$ colony forming units (CFU) and re-isolation. After each passage, bacteria were suspended in a sterile saline solution $(0.85 \% \mathrm{NaCl})$. Two treatments were applied: control fish (25 fish per tanks, three tanks, 75 fish in total) were injected with $0.1 \mathrm{~mL}$ of the sterile saline solution; infected fish (25 fish per tank, nine tanks, 225 fish in total) were injected with $1 \times 10^{6} \mathrm{CFU} / \mathrm{mL}$ of $\mathrm{LBH}$ intraperitoneally. During the experiment, the water (dechlorinated) in the experimental tanks was maintained at $20 \pm$ $1^{\circ} \mathrm{C}$, pH 6-7, dissolved oxygen above $6 \mathrm{mg} / \mathrm{L}$, and nitrite below $1 \mathrm{mg} / \mathrm{L}$. Fish were observed daily throughout the experimental period.

\section{Hematological analysis}

Blood samples were collected from 15 fish per tank at 1, 3, and 5 days after the onset of the experiment. Fish were captured with nets and quickly anaesthetized with AQUI-S 10 according to the manufacturer's manual. Blood was drawn from the caudal vein using 1-mL disposable syringes. Hematocrit (Ht) was measured as the volume of packed erythrocytes using a micro-hematocrit centrifuge (RPM12000, Hawksley, Sussex, UK), and hemoglobin $(\mathrm{Hb})$ was determined by the cyanhemoglobin method. Total leukocyte count (TLC) was determined in a Neubauer chamber using Natt and Herrick's solution as the diluent. Differential leukocyte counts were carried out using blood smears stained with May-Grünwald Giemsa (13). The morphological features of differential leukocytes were determined according to Gao et al. (14). One hundred leukocytes were randomly selected from three slides per fish for measuring erythrocyte size (i.e., the length of the longest axis) in an oil immersion under the light microscope, using the measuring function of the imaging software (cellSens Entry, Olympus, Tokyo, Japan). Total protein (TP), total calcium (Ca), urea (UA) and glucose (GLU) concentrations, 
as well as alkaline phosphatase (ALP), aspartate aminotransferase (AST), alanine aminotransferase (ALT) and lactate dehydrogenase (LDH) activities in the plasma were measured using an automatic dry chemistry analyzer (DRI-CHEM 3500i, Fuji, Tokyo, Japan).

\section{Histopathological analysis}

Liver, spleen, and kidney tissues were aseptically collected from the same 15 fish used for blood sampling and hematological analysis. Those tissues were fixed in 10\% neutral buffered formalin, dehydrated in a graded series of ethanol, and embedded in paraffin block preparation. Tissue sections were cut at $5 \mu \mathrm{m}$, mounted on slides, stained in hematoxylin and eosin (H\&E), and observed under the light microscope and photographed for histopathological examination.

\section{Statistical analysis}

Results are expressed as means \pm standard deviation (SD). Hematological data were analyzed in SPSS 7.5 for Windows using one-way analysis of variance (ANOVA), followed by Tukey's post-hoc test to determine significance differences among groups, considering $P<0.05$.

\section{Results}

\section{Clinical signs of disease and gross lesions}

Mud loach began to show clinical signs of disease and morbidity two days after inoculation with A. sobria. At three to five days post-infection (PI), the skin of infected fish presented cutaneous petechial hemorrhages on caudal and pectoral fins and abdominal and lateral body (Figure 1A). Petechiae were also found on the mouth, isthmus, cheek, operculum (Figure 1B) and caudal and pectoral fins presented hyperemia at their bases (Figure 1C). Infected fish became lethargic and developed rapid opercular movements and pale gills before dying. Internally, infected fish

Figure 1: Hemato-biochemical characteristics of mud loach, Misgurnus mizolepis, experimentally infected with Aeromonas sobria. The mud loach displayed hemorrhage on the lateral portion of body (A), operculum, cheek (B), and fin base (C). exhibited liver enlargement on day 2 PI, and then became pale, softened, and presented punctuate hemorrhage over the next $24 \mathrm{~h}$. Kidney and spleen of infected fish showed enlargement and anemia on days 2 to 5 PI. During the experimental period, cumulative mortality occurred at a rate of $13.7 \%$ (31 of the 225 fish). No clinical sings, macroscopic lesions and mortality occurred in control fish.

\section{Hemato-biochemical characteristics}

Regarding erythrocyte parameters, Ht level of infected fish was lower than that of control fish on day 1 PI (Table 1), and Ht reductions tended to be more severe in infected groups on days 3 and 5 $\mathrm{PI}$. The $\mathrm{Hb}$ level of infected fish was slightly lower than that of control fish, although this difference was not statistically significant on day 1 PI. The level was further reduced on days 3 and 5 PI. The TLC of infected fish was higher than that of control fish by day 3 PI, but it dramatically decreased on day 5 PI. Infected fish showed higher AST, ALT, and LDH activities and UA levels than control fish on day $1 \mathrm{PI}$, and these levels were considerably increased on days 3 and 5 PI. The levels of TP, ALP, $\mathrm{Ca}$, and GLU were slightly reduced in infected fish compared to control fish at day 1 PI, but on days 3 and 5 PI, significant reductions were observed.
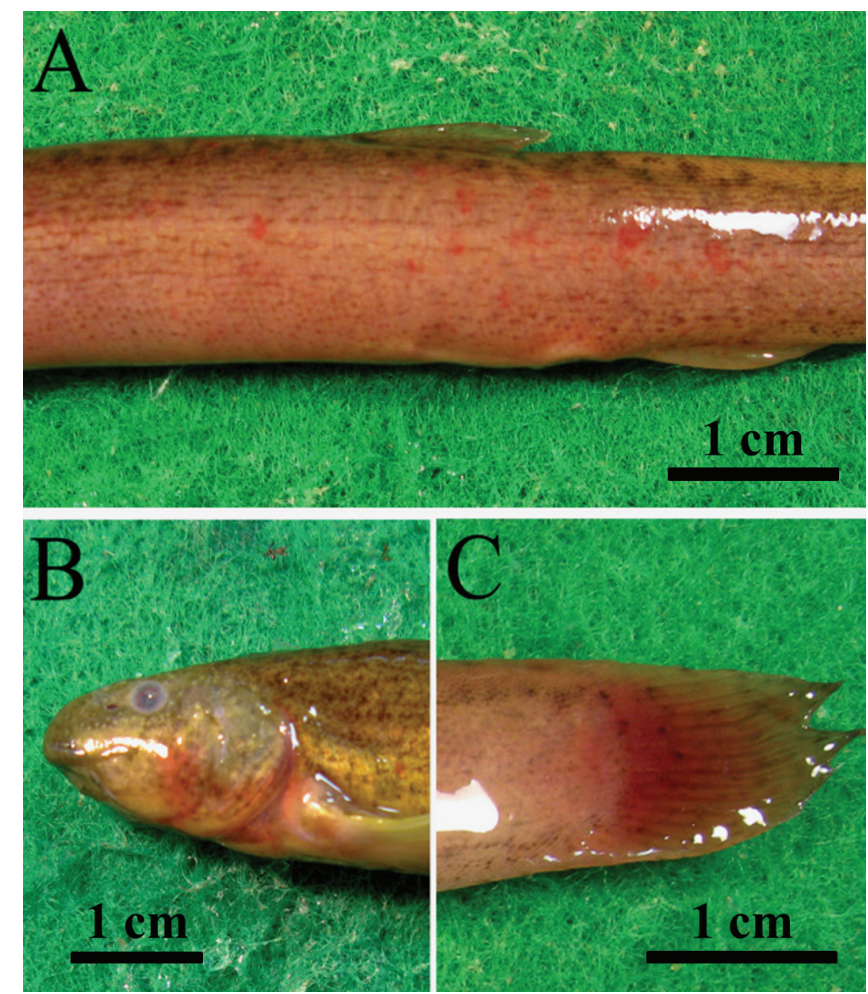
Table 1: Hemato-biochemical characteristics of mud loach, experimentally infected with Aeromonas sobria

\begin{tabular}{|c|c|c|c|c|}
\hline \multirow{2}{*}{$\begin{array}{l}\text { Hemato-biochemical character- } \\
\text { istics }\end{array}$} & \multirow{2}{*}{ Control } & \multicolumn{3}{|c|}{ Days post-infection } \\
\hline & & Day 1 & Day 3 & Day 5 \\
\hline Hematocrit (\%) & $37.8 \pm 1.2^{\mathrm{a}}$ & $30.7 \pm 5.2^{\mathrm{a}}$ & $22.7 \pm 2.2^{\mathrm{b}^{* *}}$ & $13.3 \pm 3.0^{\mathrm{c}^{* *}}$ \\
\hline Hemoglobin (g/dL) & $5.4 \pm 0.5^{a}$ & $5.0 \pm 1.0^{\mathrm{a}}$ & $4.2 \pm 2.2^{\mathrm{b}}$ & $2.8 \pm 2.8^{\mathrm{c}^{*}}$ \\
\hline Erythrocyte diameter $(\mu \mathrm{m})$ & $8.2 \pm 0.3^{a}$ & $8.2 \pm 0.3^{a}$ & $7.5 \pm 0.6^{b}$ & $6.9 \pm 0.5^{\mathrm{c}^{*}}$ \\
\hline $\operatorname{TLC}\left(10^{3} / \mathrm{mm}^{3}\right)$ & $80.5 \pm 3.5^{a}$ & $90.5 \pm 5.6^{b^{*}}$ & $101.5 \pm 6.0^{\mathrm{c}^{* *}}$ & $55.5 \pm 3.5^{d}$ \\
\hline Total Protein (g/L) & $5.7 \pm 0.6^{\mathrm{a}}$ & $4.6 \pm 0.2^{b}$ & $3.9 \pm 0.5^{\mathrm{c}^{* *}}$ & $2.8 \pm 0.7^{\mathrm{d}^{* *}}$ \\
\hline $\operatorname{ALP}(\mathrm{KA})$ & $8.0 \pm 1.2^{a}$ & $7.7 \pm 0.7^{a}$ & $5.9 \pm 0.6^{b^{* *}}$ & $4.0 \pm 1.7^{\mathrm{b}^{* *}}$ \\
\hline Total Calcium (mg/dL) & $10.8 \pm 0.3^{a}$ & $10.9 \pm 1.5^{a}$ & $8.4 \pm 1.3^{\mathrm{b}^{*}}$ & $6.3 \pm 1.0^{\mathrm{c}^{* *}}$ \\
\hline Urea (mg/dL) & $5.8 \pm 0.4^{a}$ & $6.6 \pm 2.0^{\mathrm{ab}}$ & $9.3 \pm 1.6^{\mathrm{c}^{* *}}$ & $13.8 \pm 2.1^{\mathrm{d}^{* *}}$ \\
\hline AST (U/L) & $109.3 \pm 22.8^{a}$ & $145.0 \pm 14.6^{b^{* *}}$ & $200.5 \pm 28.1^{\mathrm{c}^{* *}}$ & $312.0 \pm 35.0^{\mathrm{d}^{* *}}$ \\
\hline ALT (U/L) & $22.5 \pm 6.8^{a}$ & $38.7 \pm 5.0^{\mathrm{b}^{*}}$ & $56.0 \pm 6.3^{\mathrm{c}^{* *}}$ & $79.0 \pm 10.8^{\mathrm{d}^{* *}}$ \\
\hline $\mathrm{LDH}(\mathrm{U} / \mathrm{L})$ & $322.9 \pm 36.6^{a}$ & $459.3 \pm 68.5^{b^{*}}$ & $727.8 \pm 60.2^{\mathrm{c}^{* *}}$ & $822.8 \pm 59.9^{\mathrm{d}^{* *}}$ \\
\hline Glucose (mg/dL) & $195.7 \pm 24.4^{\mathrm{a}}$ & $198.8 \pm 18.9^{a}$ & $115.3 \pm 21.9^{b^{* *}}$ & $80.5 \pm 14.5^{\mathrm{c}^{* *}}$ \\
\hline
\end{tabular}

\section{(A)}

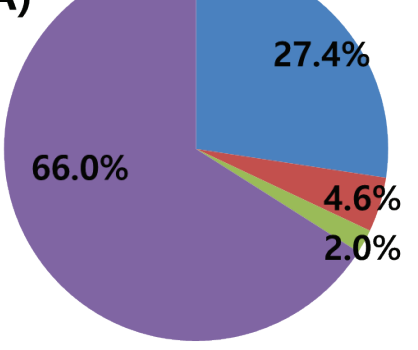

(C)

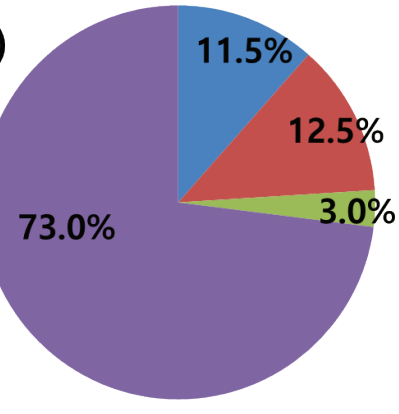

(B)

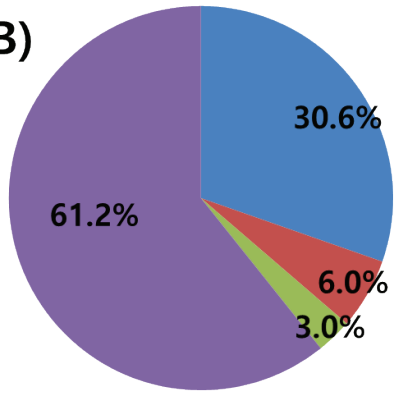

(D)

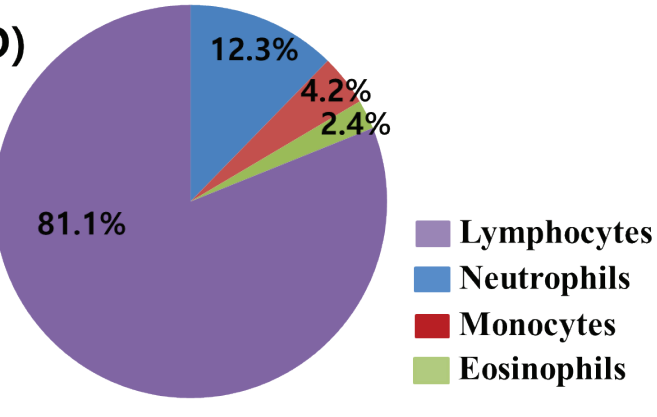

Figure 2: Leukograms of mud loach, Misgurnus mizolepis, in the control group (A), and at days $1(\mathrm{~B}), 3(\mathrm{C})$, and 5 (D) post-infection with Aeromonas sobria. 
Table 2: Frequency (\%) of erythrocytes in each diameter range in mud loach experimentally infected with Aeromonas sobria

\begin{tabular}{|c|c|c|c|c|}
\hline \multirow{2}{*}{ Range of erythrocytes diameter $(\mu \mathrm{m})$} & \multirow{2}{*}{ Control } & \multicolumn{3}{|c|}{ Days post-infection } \\
\hline & & Day 1 & Day 3 & Day 5 \\
\hline $5.5-6.0$ & & & 1 & 4 \\
\hline $6.1-6.5$ & & & 4 & 18 \\
\hline $6.6-7.0$ & & & 15 & 39 \\
\hline $7.1-7.5$ & 1 & & 29 & 25 \\
\hline $7.6-8.0$ & 39 & 38 & 38 & 13 \\
\hline $8.1-8.5$ & 48 & 49 & 9 & 1 \\
\hline $8.6-9.0$ & 11 & 12 & 4 & \\
\hline $9.1-9.5$ & 1 & 1 & & \\
\hline Number of fish examined & 15 & 15 & 15 & 15 \\
\hline
\end{tabular}

Figure 3: Histopathology of diseased mud loach, Misgurnus mizolepis, experimentally infected with Aeromonas sobria. On day 5 post-infection (PI), the kidney exhibited extensive parenchymal hemorrhage (A, arrow), severe tubular necrosis (B, arrows), accumulation of proteinaceous substances in the tubular lumen (B, white arrowheads) and hemosiderin granules (B, white arrows). On day 3 PI (C), the liver displayed atrophied cells and some hemosiderins (arrows) nearby bile ducts. Hepatocytes showed severely necrotic foci with karyopyknosis (arrowheads), karyolysis (white arrows), and hyperchromatosis (arrows) of the nuclear membrane at day 5 PI (D). Splenic pulps presented large hemosiderins (arrows) surrounded by fibrins with some glassy eosinophilic materials (white arrows) at day 3 PI (E). On day 5 PI, the spleen (F) showed severe hemorrhage, eosinophilic materials (white arrows), deposition of hemosiderins (arrows), and destruction of sheathed tissue (asterisk)
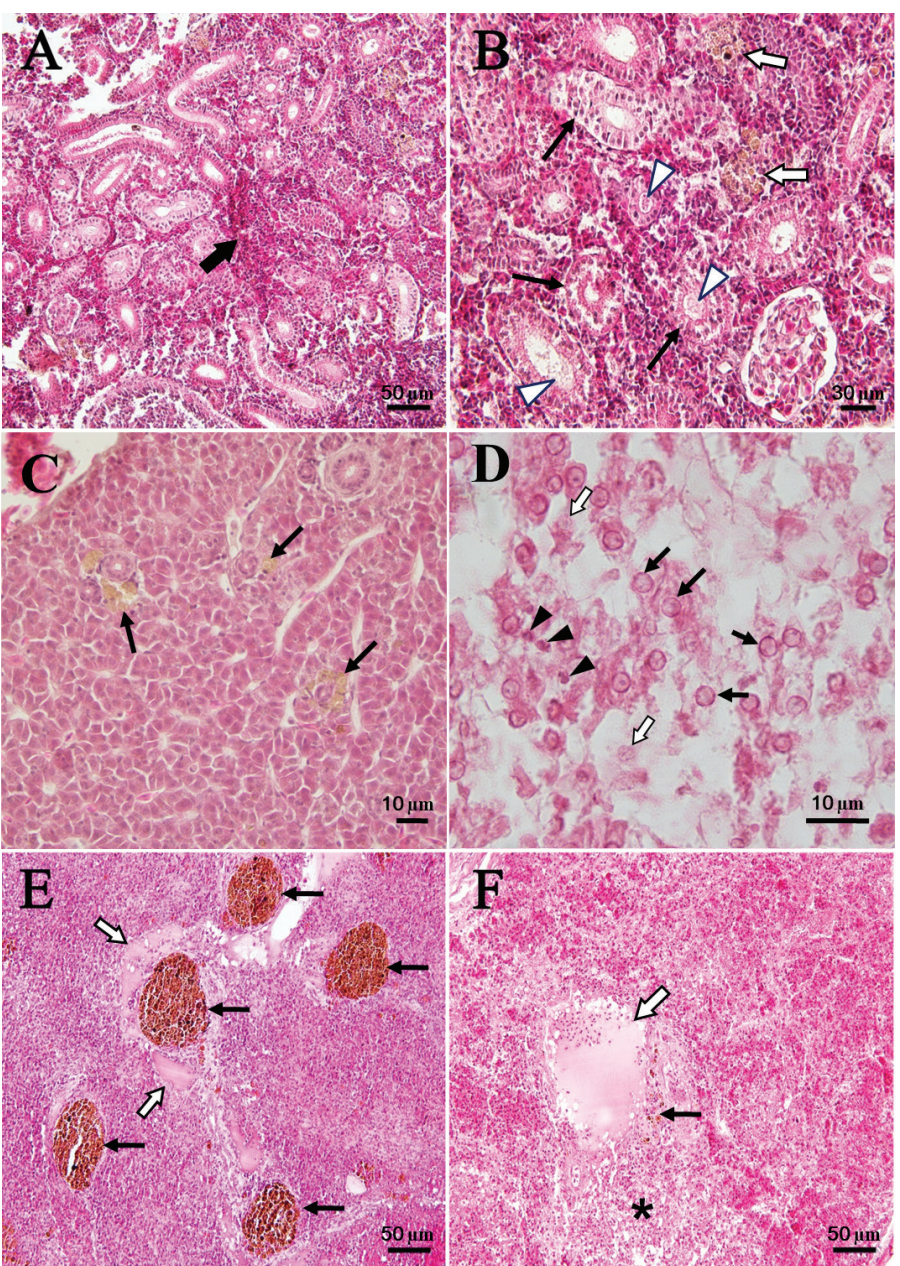
Different superscript letters indicate significant differences among experimental groups. Single and double asterisks indicate significant differences at $P<0.05$ and $P<0.01$, respectively, between experimental and control groups.

TLC, Total leukocyte count; TP, total protein; ALP, alkaline phosphatase; Ca, calcium; AST, aspartate aminotransferase; ALT, alanine aminotransferase; LDH, lactate dehydrogenase

Leukograms showed the predominance of lymphocytes and neutrophils during the experimental period (Figure 2). On day 1 PI, neutrophil and monocyte numbers in infected fish increased in relation to control whereas there were no significant changes in the number of lymphocytes and eosinophils. On day 3 PI, there were significantly more lymphocytes and monocytes in infected fish than in control fish, while there were significantly less neutrophils. On day 5 PI, lymphocytes continuously increased whereas monocytes decreased. No significant changes were observed in the number of eosinophils between infected and control groups.

As evidenced in Table 2, at the beginning of the experiment, $39 \%$ of the circulating erythrocytes ranged from 7.6 to $8.0 \mu \mathrm{m}$, but by day $5 \mathrm{PI}$, the size of the erythrocytes of the infected group had decreased to $13 \%$, compared to the size of the erythrocytes of the control group. These erythrocytes appeared as elliptical cells with an oval, central or nearly central, dark purple-stained nucleus and a blue-gray stained cytoplasm (data not shown). At day 3 PI, $4 \%$ of the measured erythrocytes ranged from 6.1 to $6.5 \mu \mathrm{m}$, but on day 5 PI erythrocytes within this range increased to $18 \%$ of the total number of erythrocytes. These cells were round with centrally positioned, round nuclei in a dark-blue-stained cytoplasm; they were considered reticulocytes based on Gao et al. (14) classification.

\section{Histopathology}

No histopathological symptoms were observed in tissues of infected fish at day 1 PI. However, on day 3 PI, there was extensive hemorrhaging in the kidney with generalized necrosis of hematopoietic tissue and accumulation of eosinophilic proteinaceous substances in the lumen of necrotized renal tubules (Figure 3A and 3B). Extensive hemorrhage in the parenchyma and peritubular region with renal tubular necrosis continued until day 5 PI. Atrophy of hepatic cells and some hemosiderins appeared nearby bile ducts at day 3 PI (Figure 3C). On day 5 PI, liver cells showed severely necrotic foci with karyopyknosis, karyorrhexis, karyolysis and hyperchromatosis of the nuclear membrane (Figure 3D). In the spleen, pulps were hemorrhaged, sheathed tissue was destroyed, and many hemosiderins were surrounded by fibrins with some glassy eosinophilic materials (hyaline droplet degeneration) (Figure $3 \mathrm{E}$ and $3 \mathrm{~F}$ ) on days 3 to 5 PI. Control fish showed no histological lesions in visceral organs (data not shown).

\section{Discussion}

Bacterial pathogens such as Aeromonas spp. cause significant hematological and histological changes, which lead to mass mortalities of freshwater fish $(7,15,16)$. In the present study, we found hematological and histological alterations in mud loach infected with $A$. sobria.

Erythrocytes contain hemoglobin, which facilitates the transportation of oxygen by reversibly bonding the respiratory gas, thereby increasing its solubility in blood (17). Both $\mathrm{Ht}$ and $\mathrm{Hb}$ are good indicators of fish oxygen transportation capacity allowing establishing a relationship between the oxygen available in the environment and fish health (18). Scott and Rogers (19) reported that reduced $\mathrm{Ht}$ and $\mathrm{Hb}$ levels are due to the mobilization of erythrocytes in combination with poor hemoglobin from the spleen to other hematopoietic organs, resulting in hypochromic anemia. Infections by Aeromonas spp. damage internal organs, especially hematopoietic organs such as the spleen and kidney $(16,20,21)$. Baruah et al. (22) suggested that anemia might be due to hemodilution caused by a loss of body fluid from hemorrhagic or necrotic lesions. In the present study, $\mathrm{Ht}$ and $\mathrm{Hb}$ levels were considerably reduced in $A$. sobria-infected fish compared to healthy fish, and this was also observed in rainbow trout, Oncorhynchus mykiss (15), common carp, Cyprinus carpio (23), striped snakeheads, Channa striatus (24), and Nile tilapia, Oreochromis niliticus (25) infected with different bacterial pathogens. In the present study, mud loach infected with $A$. sobria showed severe hemorrhage with necrosis and deposition of hemosiderins (hemolysis) in the kidney and spleen. Overall, these results indicate 
that reduction of $\mathrm{Ht}$ and $\mathrm{Hb}$ levels observed in infected fish might be attributed to the impairment of oxygen carrying capacity by A. sobria and/or to damage in hematopoietic organs.

Infected mud loach showed an increase in the proportion of reticulocytes (immature erythrocytes) on day 3 PI, which continued to increase until day 5 PI. The appearance of immature erythrocytes in the circulation might reflect the pathophysiological alterations that occur as infected fish attempt to maintain homeostasis (26).

Leukocytes are important components of the immune system and play critical roles in the defense against pathogen invasion $(13,17,27)$. In fact, the increase in TLC during bacterial infection is correlated to the stimulation of defense functions against pathogens $(13,17,28)$. MacArthur et al. (29) reported the migration of leukocytes from the blood and organs into sites of damaged tissue in European plaice, Pleuronectes platessa infected with Vibrio alginolyticus, corresponding to an acute cellular inflammatory response. In the present study, the TLC in infected fish increased until day 3 PI suggesting that $A$. sobria infection enhanced immunological responses by increasing leukocyte numbers in the early stage of the infection. However, on day 5 PI, there was a decrease in TLC and severe necrosis of the kidney tissue. This TLC reduction in infected mud loach might be attributed to fish losing the ability to produce leukocytes due to damage in hematopoietic tissues, which may compromise immunological functions such as phagocytosis in later stages of the infection.

The different types of leukocytes were affected by $A$. sobria infection. Neutrophils play a key role in the early stages of inflammatory response and are involved in cellular immune response, migrating to injury sites such as those resulting from bacterial or parasitic infections $(11,13,17,30)$. Pathiratne and Rajapakshe (11) and Ranzani-Paiva et al. (31) reported that fish affected by ulcerative syndromes and Mycobacterium marinum, respectively, showed more neutrophils than healthy fish. In contrast, Nile tilapia infected with Enterococcus spp. and striped snakehead infected with A. hydrophila exhibited fewer neutrophils than healthy fish (24, $25)$. In the present study, neutrophils' number increased in infected mud loach on day 1 PI but was significantly lower than that of control fish on day 3 PI. Thus, the increase in neutrophils in the early stage of the infection might be associated with the defense mechanism used to initiate and potentiate responses against the invading pathogen; as neutrophils migrate from the blood to damaged tissues to remove pathogens and cellular debris while infection develops, there is a decrease in the number of neutrophils circulating in blood.

Monocytes are phagocytic cells derived from macrophage migrating from the blood to various tissues $(25,30)$. In the present study, an increase in monocytes' percentage was observed in infected fish on day 1 PI and it remained high until day 3 PI. This increase in monocytes might be caused by their migration from hematopoietic tissues into circulating blood to orchestrate immune responses during the early stage of infection. At the end of the experiment, the number of monocytes in infected fish was similar to that before the infection. This reduction in the monocyte population at the later stage of the infection might have resulted from their accelerated movement from the blood to damaged tissues in order to remove cell fragments and pathogens.

Lymphocytes are usually the most common type of leukocytes present in fish blood (32). In Korean catfish, Silurus asotus infected with Edwardsiella tarda, a high number of lymphocytes were observed (13). Similarly, we observed that the number of lymphocytes in A. sobria-infected mud loach considerably increased in the later stage of the infection. Although the mechanism underlying the increase in lymphocyte number in mud loach infected with $A$. sobria is still unclear these cells seem to work as immune-competent cells, as suggested by Martins et al. (25).

Eosinophils possess the necessary cellular machinery (innate immune receptors, proinflammatory cytokines, antibacterial proteins, and DNA traps) for an efficient antibacterial response (33). Yazdanbakhsh et al. (34) reported that eosinophils can phagocytize and kill several bacteria including Staphylococcus aureus and Escherichia coli, although not as efficiently as neutrophils. Striped snakehead fish affected by epizootic ulcerative syndrome showed increased eosinophils percentage (35). However, in the present study, no difference was found in eosinophil numbers between infected and control fish. Thus, eosinophils seem to play a very limited role in bacterial responses, especially in systemic bacterial acute infections.

Thereduction ofTP in fish reflects theimpairment 
of protein re-absorption in renal tubules (36), and Rehulka and Minařik (37) suggested that protein loss in brook trout, Salvelinus fontinalis, affected by columnaris disease could be caused by external lesions, kidney damage, and reduction of protein synthesis in the liver. We observed that the renal tubules of infected mud loach were severely necrotized and presented abundant hemorrhage, suggesting that TP reduction might be due, at least partially, to kidney damage and protein loss after A. sobria infection. However, other mechanisms such as reduced hepatic protein synthesis and renal re-absorption should be considered.

As aleakage enzyme, AST highest concentrations are found in the cytoplasm of hepatocytes of all species, in the cytoplasm with only about $20 \%$ located within mitochondria $(38,39)$; ALT is present in high concentrations in liver and to a lesser extent in the skeletal muscle, kidney, and heart (40). The levels of these enzymes increase in the plasma when hepatic cells are damaged or their membranes disrupted, allowing the enzymes to leak out $(22,41)$. Řehulka and Minařík (37) assumed that increased ALT levels signaled liver cell insufficiency, that and increased AST levels signaled a serious damage to the liver with the release of the mitochondrial AST in brook trout affected by columnaris disease. A significant increase in both enzymes has also been reported in various fish infected with Serratia liquefaciens (41), Aphanomyces invadans (22), Cyprinid herpesvirus-2 (42), and A. salmonicida (43). According to Jeney et al. (44), increased AST levels in the plasma reflected tissue damage, probably due to the necrosis of hematopoietic tissues in Wels catfish, Silurus glanis, infected with a new serotype of Rhabdovirus carpio. Because ALP is an induced enzyme that is attached to cell membranes and synthesized by many tissues such as liver, pancreas, kidney, and intestine (38, $39)$, it plays an important role in the transport of metabolites across membranes and is involved in the synthesis of several enzymes (45). Columnaris disease (37) and $V$. anguillarum (46) or E. tarda (13) infections cause a decrease in ALP levels that correlates with signs of anemia. Increased AST and ALT levels and a reduced ALP level in the case of vibriosis have been described in Coho salmon, Oncorhynchus kisutch (46) and Atlantic salmon, Salmo salar (47). In addition, Rehulka and Minařik (37) observed an increase in AST and ALT and a decrease in ALP activities in brook trout affected by columnaris disease. Similarly, A. sobria-infected mud loach showed an increase in AST and ALT, and a decrease in ALP levels. Histologically, A. sobria caused severe damage to liver and kidney tissues, suggesting that changes in AST, ALT, and ALP levels are directly related to such damages (cell membrane damage) in internal organs. Hence, A. sobria seems to induce changes in AST, ALT, and ALP activities in the blood, as observed for other microbial infections.

Calcium (Ca) is known to combine with proteins, mainly with albumin and $30-40 \%$ of the total plasma calcium in freshwater fish is bound to proteins (48). Thus, changes in plasma proteins affect total $\mathrm{Ca}$ concentration, and reduced. $\mathrm{Ca}$ levels are related with hypoproteinemia, particularly hypoalbuminemia (37). In the present study, TP and Ca levels were reduced in infected mud loach, similar to that reported for brook trout infected with Flavobacterium columnare. Our results suggest that $A$. sobria infection causes hypocalcemia by decreasing the levels of proteinbound Ca.

Urea discharge through the kidney and the increase in its level are associated with an increased protein catabolism, due to fasting, infection and blood loss (37). Rehulka (15) demonstrated that rainbow trout infected with Aeromonas spp. had an elevated urea level, and proposed that the high urea value in infected fish arose from hypovolemia due to the decrease in glomerular filteration and increase of blood urea nitrogen absorption. An increase in UA level was also recorded in brook trout with columnaris disease (37). The UA level in the plasma of infected mud loach was significantly increased compared to that of control fish, indicating that kidneys of infected fish were damaged, which was consistent with the histopathological observations. However, Philip and Rajasree (49) suggested that the increase in UA values observed in common carp exposed to cypermethrin was caused by the increase in amino transferase activity with a concurrent increase in deamination capacity of some proteins.

Lactate dehydrogenase is found in the cytoplasm of most cells and it is released into the extracellular space and blood when tissue cells are injured (38). An increase in LDH has been reported in salmonids infected with pathogenic bacteria $(13,37)$. In the present study, we found that $A$. sobria caused a significant increase in LDH levels and severe necrosis of liver and 
kidney tissues in mud loach, suggesting that the histopathological features found in liver and kidney might be associated with an elevation in the catalytic concentration of $\mathrm{LDH}$, as proposed by Řehulka and Minařik (37).

The level of GLU in the plasma of infected mud loach was reduced compared to that of control fish. Aydin et al. (8) and Yu et al. (13) proposed that the decreased GLU levels found in rainbow trout infected with Campylobactor cryaerophila and Korean catfish infected with E. tarda, respectively, was linked to hypoglycemia, due to the decrease in the activity of liver glicogenolytic enzymes under the stress caused by the infections. Columnaris disease and $S$. liquefaciens infection also caused a reduction in the GLU values of brook trout (37) and rainbow trout (41). The reduction in the GLU level, along with the reduced activity of AST, suggested decline of hepatic protein synthesis during infection stress. In the present study, we found that $A$. sobria caused severe histological damage to liver tissue, indicating that the reduction of GLU level in plasma of infected mud loach might account for the degeneration and necrosis of hepatic tissues that lose their glycogen storage ability and metabolic functions.

In summary, we found that $A$. sobria infection causes hematological and biochemical changes such as anemia, hypoglycemia, hypoproteinemia, hypocalcemia, increase in AST, ALT and LDH activity, increased concentrations of urea and ALP reduction. These alterations lead to detrimental consequences such as compromised disease resistance, tissue damages and low survival rates. Hemato-biochemical changes were also partially accompanied by histopathological changes. Although it is difficult to conclude that natural A. sobria infection can cause hematological and biochemical alterations identical to those found under the laboratory conditions tested here, the results of the present study provide a basis for further comparative studies aiming to obtain detailed information on the pathological processes occurring in the blood and visceral organs of mud loach infected with $A$. sobria

\section{Acknowledgements}

This research was supported by the National Fishery Products Quality Management Service (NFQS), Gyeonggi Province Maritime and Fisheries
Institute, and Fisheries Science Institute of Kunsan National University.

Conflict of interest.The authors declare no conflict of interest

\section{References}

1. Kim DS, Nam YK, Park IS. Survival and karyological analysis of reciprocal diploid and triploid hybrids between mud loach (Misgurnus mizolepis) and cyprinid loach (Misgurnus anguillicaudatus). Aquaculture 1995; 135: 275-65.

2. Daily OP, Joseph SW, Coolbaugh JC, et al. Association of Aeromonas sobria with human infection. J Clin Microbiol 1981; 13: 769-77.

3. Filler G, Enrich JHH, Stauch E, Beutin L. Acute renal failure in an infant associated with cytotoxic Aeromonas sobria isolated from patient's stool and from aquarium water as suspected source of infection. J Clin Microbiol 2000; 38: 469-70.

4. Igbinosa IH, Igumbor EU, Aghdasi F, Tom M, Okoh AI. Emerging Aeromonas species infections and their significance in public health. Sci World J. 2012; 2012: e 625023 (13 p.) https://www. ncbi.nlm.nih.gov/pmc/articles/PMC3373137/

5. Toranzo AE, Baya AM, Romalde JL, Hetrick FM. Association of Aeromonas sobria with mortalities of adult gizzard shad, Dorosoma cepedianum Lesueur. J Fish Dis 1989; 12: 439-48.

6. Wahli T, Burr SE, Pugovkin D, Mueller O, Frey J. Aeromonas sobria, a causative agent of disease in farmed perch, Perca fluviatilis L. J Fish Dis 2005; 28: 141-50.

7. Yu JH, Koo BH, Kim DH, Kim DW, Park SW. Aeromonas sobria infection in farmed mud loach (Misgurnus mizolepis) in Korea, a bacteriological survey. Iranian J Vet Res 2015; 16: 194-201.

8. Aydin S, Gültepe N, Yildiz H. Natural and experimental infections of Campylobacter cryaerophila in rainbow trout: gross pathology, bacteriology, clinical pathology and chemotherapy. Fish Pathol 2000; 35(3): 117-23.

9. Camargo MMP, Martinez CBR. Histopathology of gills, kidney and liver of a Neotropical fish caged in an urban stream. Neotrop Ichthyol 2007; 5(3): 327-36.

10. Filho CI, Müller EE, Pretto-Giordano LG, Bracarense APFRL. Histological findings of experimental Streptococcus agalactiae infection in Nile tilapias (Oreochromis niloticus). Braz J Vet 
Pathol 2009; 2(1): 12-5.

11. Pathiratne A, Rajapakshe W. Hematological changes associated with epizootic ulcerative syndrome in the Asian Cichlid fish, Etroplus suratensis. Asian Fish Sci 1998; 11: 203-11.

12. Thophon S, Kruatrachue M, Upathan ES, Pokethitiyook P, Sahaphong S, Jarikhuan S. Histopathological alterations of white seabass, Lates calcarifer in acute and subchronic cadmium exposure. Environ Pollut 2003; 121: 307-20.

13. Yu JH, Han JJ, Park SW. Haematological and biochemical alterations in Korean catfish, Silurus asotus, experimentally infected with Edwardsiella tarda. Aquac Res 2010; 41: 295-302.

14. Gao $Z$, Wang $W$, Abbas $K$, et al. Haematological characterization of loach Misgurnus anguillicaudatus: comparison among diploid, triploid and tetraploid specimens. Comp Biochem Physiol A 2007; 147: 1001-8.

15. Rehulka J. Aeromonas causes severe skin lesions in rainbow trout (Oncorhynchus mykiss): clinical pathology, haematology and biochemistry. Acta Vet Brno 2002; 71: 351-60.

16. Yu JH, Han JJ, Kim HJ, Kang SG, Park SW. First report of Aeromonas veronii infection in farmed Israeli carp, Cyprinus carpio, in Korea. J Fish Pathol 2010; 23: 165-76.

17. Park SW, Oh MH. Fish and shellfish hematology. Seoul, Korea : Daekyung, 2006: 147-8.

18. Amrevuawho MO, Akinyemi AA, Ezeri GNO, Bankole OM, Takeet OVA. Pathological study of Clarias gariepinus (Burchell, 1822) sub-adult artificially infected with Pseudomonas aeruginosa. Braz J Aquat Sci Technol 2014; 18(2): 65-70.

19. Scott AL, Rogers WA. Haematological effects of prolonged sublethal hypoxia on channel catfish Ictalurus punctatus (Rafinesque). J Fish Biol 1981; 18(5): 591-601.

20. Miyzazki T, Kaige N. Histopathological study on motile aeromonad disease of crucian carp. Fish Pathol 1985; 21: 181-5.

21. Yardimci B, Aydin Y. Pathological findings of experimental Aeromonas hydrophila infection in Nile tilapia (Oreochromis niloticus). Ankara Üniv Vet Fak Derg 2011; 58: 47-54.

22. Baruah A, Saha RK, Kamilya D. Inter-species transmission of the epizootic ulcerative syndrome (EUS) pathogen, Aphanomyces invadans, and associated physiological responses. Isr J Aquac Bamidgeh 2012; 64: 1-9. https://evols.library. manoa.hawaii.edu/handle/10524/22928

23. Harikrishnan R, Nisha RM, Balasundaram
C. Haematological and biochemical parameter in common carp, Cyprinus carpio, following herbal treatment for Aeromonas hydrophila infection. Aquaculture 2003; 221: 41-50.

24. Haniffa MA, Abdul KMKP. Hematological changes in Channa striatus experimentally infected by Aeromonas hydrophila. Bio Bull 2011; 4: 246-53.

25. Martins ML, Mouriño JL, Amaral GV, et al. Haematological changes in Nile tilapia experimentally infected with Enterococcus sp. Braz J Biol 2008; 68: 657-61.

26. Tedawy FAA, Sallam AA, Gorgy SF. Biochemical changes associated with Aeromonas hydrophila infection in cultured Oreochromis species. Banha Vet Med J 2011; 1: 179-90.

27. Vázquez GR, Guerrero GA. Characterization of blood cells and hematological parametersin Cichlasoma dimerus (Teleostei, Perciformes). Tissue Cell 2007; 39: 151-60.

28. Caruso D, Schlumberger O, Daham C, Proteau JP. Plasma lysozyme levels in sheatfish, Silurusglanis (L.) subjected to stress and experimental infection with Edwardsiella tarda. Aquac Res 2002; 33: 999-1008.

29. MacArthur JI, Fletcher TC, Pirie BJS, Davidson RJL, Thomson AW. Peritoneal inflammatory cells in plaice, Pleuronectes platessa $\mathrm{L}$ : effects of stress and endotoxin. J Fish Biol 1984; 25: 69-81.

30. Benjamini E, Coico R, Sunshine G. Immunology. $4^{\text {th }}$ ed. New York : Wiley-Liss, 2000: 21-2.

31. Ranzani-Paiva MJT, Ishikawa CM, Cocuzza das Eiras A, Risaffi da Silveira V. Effects of an experimental challenge with Mycobacterium marinum on the blood parameters of Nile tilapia, Oreochromis niloticus (Linnaeus, 1757). Braz Arch Biol Technol 2004; 47: 945-53.

32. Groff JM, Zinkl JG. Hematology and clinical chemistry of Cyprinid fish. Common carp and goldfish. Vet Clin N Am Exot Anim Pract 1999; 2 (3): 741-6.

33. Hogan SP, Waddell A, Fulkerson PC. Eosinophils in infection and intestinal immunity. Curr Opin Gastroenterol 2013; 29(1): 7-14.

34. Yazdanbakhsh M, Eckmann CM, Bot AA, Roos D. Bactericidal action of eosinophils from normal human blood. Infect Immun 1986; 53: 192-8.

35. Koteshwar RP, Benarjee G. Haematological changes in fresh water fish, Channa striatus 
diagnosed with the epizootic ulcerative syndrome (EUS). Int J Adv Biotech Res 2015; 6: 238-44.

36. Hoffman R, Lommel R. Haematological studies in proliferative kidney disease of rainbow trout, Salmo gairdneri Richardson. J Fish Dis 1984; 7: 323-6.

37. Řehulka J, Minařik B. Blood parameters in brook trout Salvelinus fontinalis (Mitchill, 1815), affected by columnaris disease. Aquac Res 2007; 38: 1182-97.

38. Boyd JW. The mechanisms relating to increases in plasma enzymes and isoenzymes in diseases animals. Vet Clin Pathol 1983; 12: 9-24.

39. Keller P. Enzyme activities in the dog: tissue analyses, plasma values, and intracellular distribution. Am J Vet Res 1981; 42: 575-82.

40. Zilva JF, Pannall PR, Mayne PD. Clinical chemistry in diagnosis treatment. $6^{\text {th }}$ ed. London: E. Arnold, 1992: 287-306.

41. Aydin S, Erman Z, Bilgin ÖC. Investigation of Serratia liquefaciens infection in rainbow trout (Oncorhynchus mykiss Walbaum). Turk J Vet Anim Sci 2001; 25: 643-50.

42. Lu J, Lu H, Cao G. Hematological and histological changes in Prussian carp Carassius gibelio infected with Cyprinid Herpesvirus 2. J Aquat Anim Health 2016; 28: 150-60.

43. Shieh HS. Changes of blood enzymes in brook trout induced by infection with Aeromonas salmonicida. J Fish Biol 1978; 12: 13-8.

44. Jeney G, Jeney Z, Oláh J, Fijan N. Effect of rhabdovirus infection on selected blood parameters of Wels. Aquac Hung (Szarvas) 1990; 6: 153-60.

45. Rai AK, Saikia P, Mech B. Histochemical localization of alkaline phosphatase activity during cutaneous wound healing in a catfish under acid stress. Int J Sci Res Publ 2013; 3(8): 1-9.

46. Harbell SC, Hodgins $\mathrm{HO}$, Schiewe MH. Studies on the pathogenesis of vibriosis in Coho salmon, Oncorhynchus kisutch (Walbaum). J Fish Dis 1979; 2(5): 391-404.

47. Waagbø R, Sandnes K, Espelid S, Kie Ø. Haematological and biochemical analyses of Atlantic salmon, Salmo salar L., suffering from coldwater vibriosis ('Hitradisease'). J Fish Dis 1988; 11: 417-23.

48. Thrall MA, Weiser G, Allison RW, Campbell TW. Veterinary hematology and clinical chemistry. In: Campbell W, eds. Clinical chemistry of fish and amphibians. Ames : Wiley-Blackwell, 2012: 607-14.

49. Philip GH, Rajasree BH. Action of cypermethrin on tissue transamination during nitrogen metabolism in Cyprinus carpio. Ecotoxicol Environ Saf 1996; 34: 174-9. 


\title{
HEMATOLOŠKO-BIOKEMIČNE IN HISTOPATOLOŠKE SPREMEMBE PRI ČINKLJAH (Misgurnus mizolepis), EKSPERIMENTALNO OKUŽENIH Z Aeromonas sobria
}

\author{
J.H. Yu, J.J.Han, D.H. Kim, S.W. Park
}

Povzetek: V raziskavi so bile preučevane hematološko-biokemične in histopatološke spremembe pri činkljah (Misgurnus mizolepis), okuženih z Aeromonas sobria. Ribe, okužene z $1 \times 10^{6}$ kolonij/ml A. sobria (25 rib x 3 ponovitve v 3 bazenih) in neokužene (kontrolne) ribe (25 rib x 3 ponovitve $\vee 3$ bazenih) so bile nastanjene v laboratorijskih akvarijih z ustreznimi parametri vode in bile evtanazirane 1., 3. in 5. dan po okužbi (PI). V petdnevnem poskusnem obdobju so okužene ribe postale letargične, škržne poklopce so hitro odpirale in zapirale, njihove škrge so postale blede in opazne so bile podkožne petehialne krvavitve. Hematološko-biokemični parametri, in sicer hematokrit, hemoglobin, celokupna količina beljakovin, celokupni kalcij, aktivnost alkalne fosfataze (ALP) in nivo glukoze so bili znatno zmanjšani, medtem ko so bili sečnina (UA), aspartat aminotransferaza (AST), alanin-aminotransferaza (ALT) in laktat dehidrogenaza (LDH) v okuženih ribah opazno povečani v primerjavi s kontrolno skupino rib. Skupno število levkocitov je bilo večje pri okuženih kot pri kontrolnih ribah po 3. dnevu PI, vendar se je 5. dan PI dramatično zmanjšalo. V beli krvni sliki so med obdobjem poskusa prevladovali limfociti in nevtrofilci. Histološka slika ledvic in vranice je pokazala obsežne krvavitve s celično nekrozo. Vhepatocitih so bila vidna močno nekrotična žarišča s kariopiknozo, karioheksijo, kariolizo in hiperhromatozo jedrne membrane. Okužba z A. sobria je povzročila hematološko-biokemične spremembe, kot so anemija, hipoglikemija, hipoproteinemija, hipokalcemija, povečane aktivnosti AST, ALT in LDH, povečane koncentracije UA in zmanjšana aktivnost ALP, kar je privedlo do zmanjšane odpornosti na bolezen, poškodbe tkiva in nizke stopnje preživetja.

Ključne besede: Aeromonas sobria; hematologija; histopatologija; Misgurnus mizolepis 